2016

\title{
Funerary Offerings from the Keasler Site Cemetery (41HS235), Harrison County, Texas
}

Timothy K. Perttula

Heritage Research Center, Stephen F. Austin State University

Mark Walters

Heritage Research Center, Stephen F. Austin State University

Bo Nelson

Heritage Research Center, Stephen F. Austin State University

Follow this and additional works at: https://scholarworks.sfasu.edu/ita

Part of the American Material Culture Commons, Archaeological Anthropology Commons, Environmental Studies Commons, Other American Studies Commons, Other Arts and Humanities Commons, Other History of Art, Architecture, and Archaeology Commons, and the United States History Commons

Tell us how this article helped you.

This Article is brought to you for free and open access by the Center for Regional Heritage Research at SFA ScholarWorks. It has been accepted for inclusion in Index of Texas Archaeology: Open Access Gray Literature from the Lone Star State by an authorized editor of SFA ScholarWorks. For more information, please contact cdsscholarworks@sfasu.edu. 


\section{Funerary Offerings from the Keasler Site Cemetery (41HS235), Harrison County,}

Texas

\section{Creative Commons License}

\section{(c) (1) (8)}

This work is licensed under a Creative Commons Attribution-NonCommercial 4.0 International License 


\title{
Funerary Offerings from the Keasler Site Cemetery (41HS235), Harrison County, Texas
}

\author{
Timothy K. Perttula, Mark Walters, and Bo Nelson
}

\section{INTRODUCTION}

The Keasler site (41HS235) is a post-ca. A.D. 1430 Late Caddo period, Titus phase cemetery with at least 31 burials in the East Texas Pineywoods (Figure 1) (Perttula 2015). The site was excavated by collectors in the late 1970s on the property of Sid Keasler of Hallsville, Texas. Minimal records on the burials at the site, and their contents, were provided by Red McFarland, one of the collectors, to the Texas Archeological Research Laboratory at The University of Texas (TARL).

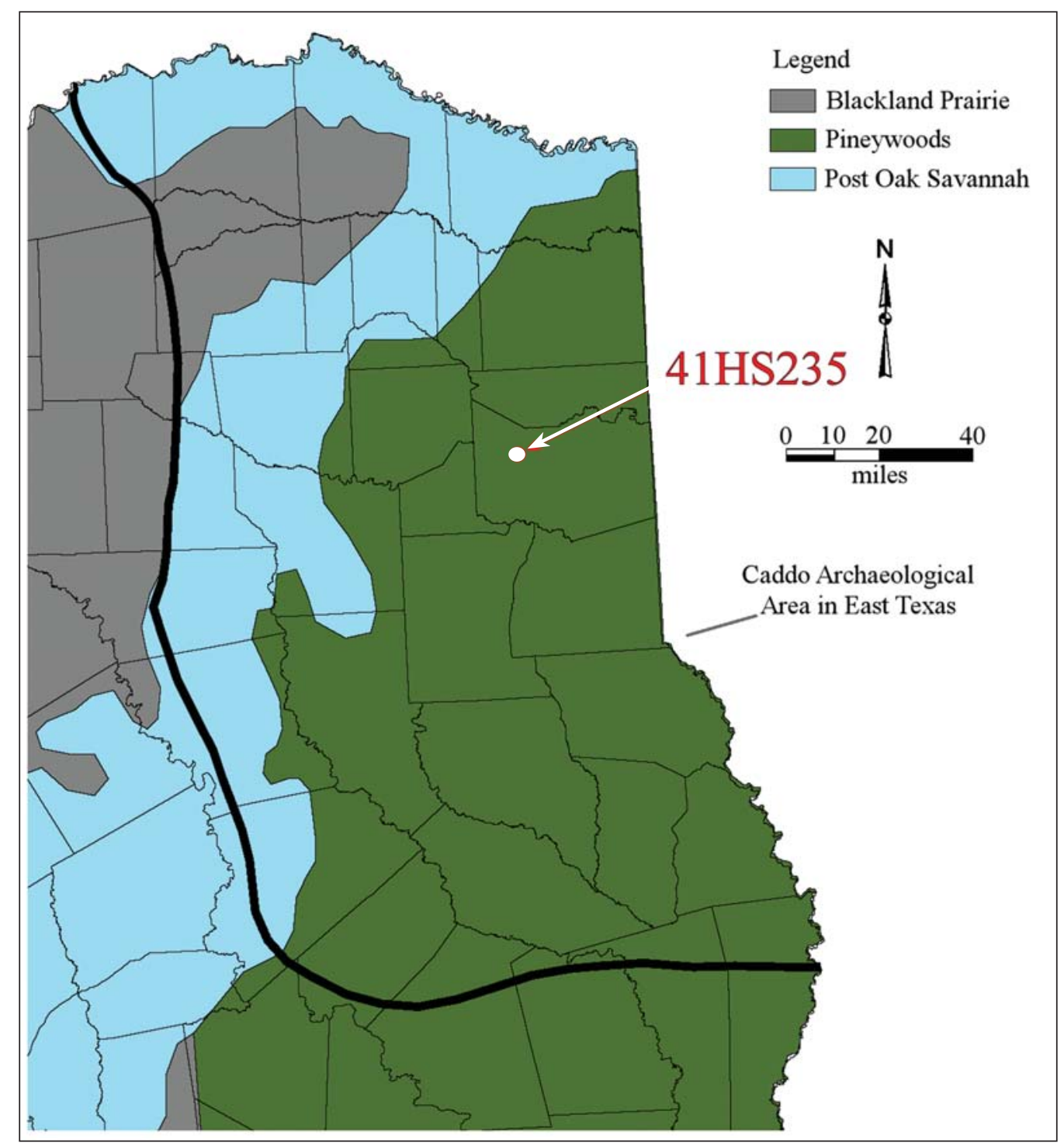

Figure 1. The location of the Keasler site (41HS235) in East Texas. 
The Keasler site is near Little Creek, a northward-flowing tributary to Little Cypress Creek. It is perhaps one of the easternmost-known Titus phase cemeteries in East Texas (see Perttula 2012:Figure 13-2 and Table 13-3), in an area where few Titus phase sites or cemeteries have been identified or investigated by professional archaeologists. Based on the analysis of the available records and vessel images at TARL, Perttula (2015) noted that funerary offerings in the burials primarily included ceramic vessels - both utility and fine waresin almost all of the burials, along with clay pipes and arrow points in only a few of the graves. The subtle differences between two different burial groups in the number and kind of funerary offerings in the cemetery do not provide much evidence of differential status or social rank (e.g., Burden et al. 2014), and the frequency of funerary offerings as attested to in the TARL records (see Perttula 2015) is at the low end of the scale in Titus phase cemeteries. The burials at the Keasler site appear to be those of common members of the Caddo community living in the lower part of the Little Cypress Creek basin. The range of decorated utility ware and fine ware vessels placed in the burial features are consistent with use of the cemetery by ancestral Caddo peoples in parts of the $16^{\text {th }}$ and $17^{\text {th }}$ centuries A.D. (Perttula 2015).

Subsequent to the analysis of the available records at TARL from the Keasler site, funerary offerings from the site in the Sid Keasler collection have come to light. In July 1999, Mark Walters and Bo Nelson photo-documented the Keasler collection, which represents approximately 50 percent of the funerary offerings recovered by Red McFarland. This article summarizes the character of the funerary offerings in the collection. Walters also recorded the nearby Pine Grove site (41HS826), which may represent one habitation area associated with the use of the cemetery at the Keasler site by ancestral Caddo peoples.

\section{Funerary Offerings}

The funerary offerings in the Sid Keasler collection from the Keasler site include both ceramic and lithic artifacts. The ceramic artifacts comprise 69 vessels and portions of three ceramic pipes. The lithic artifacts in the collection from burial contexts consist of 17 arrow points and five ground stone celts.

\section{Plain Ware Vessels}

Approximately 10 percent of the ceramic vessels are plain wares. These plain ware vessels include one everted rim jar (Figure 2a), one bowl (Figure 2b), a carinated bowl (Figure 2c), and four bottles (Figure 2dg). One of the plain bottles has a collared neck (Figure 2g).

\section{Utility Ware Vessels}

There are 18 utility ware vessels in the Keasler collection from the Keasler site cemetery; this represents 26 percent of the vessel assemblage in the collection. More than 94 percent of the utility ware vessels are jars, but there is one bone-tempered brushed bottle in the collection (Figure 3a).

In addition to the brushed bottle, there are eight everted rim jars with brushed decorations on the rim and body; these are Bullard Brushed vessels (see Figure 3b-g). One vase-shaped jar (see Figure 3h) may be a Karnack Brushed-Incised vessel.

Another jar in the collection has a vertically brushed body and a row of tool punctations at the rim-body juncture (Figure 4a), and a short rimmed jar has vertical brushing marks on the vessel body between vertical appliqued ridges (Figure 4b). A third jar has rows of large punctations on the rim, large vertical appliqued fillets on the vessel body, and vertical brushing marks on the vessel body (Figure 4c). One very distinctive jar has a series of large circular cane punctations covering the exterior surface of the jar from the rim to the base (Figure 4d). 


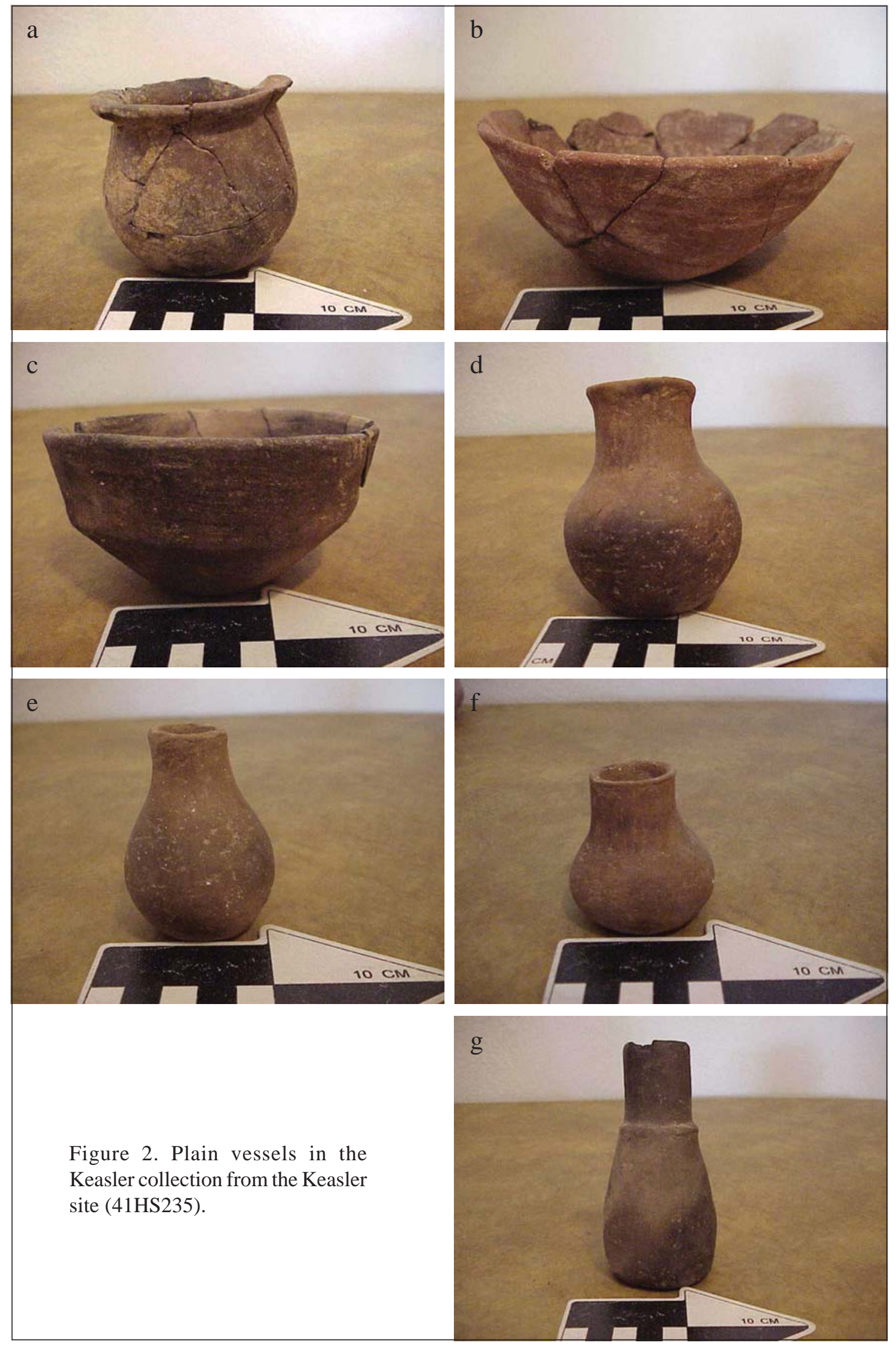



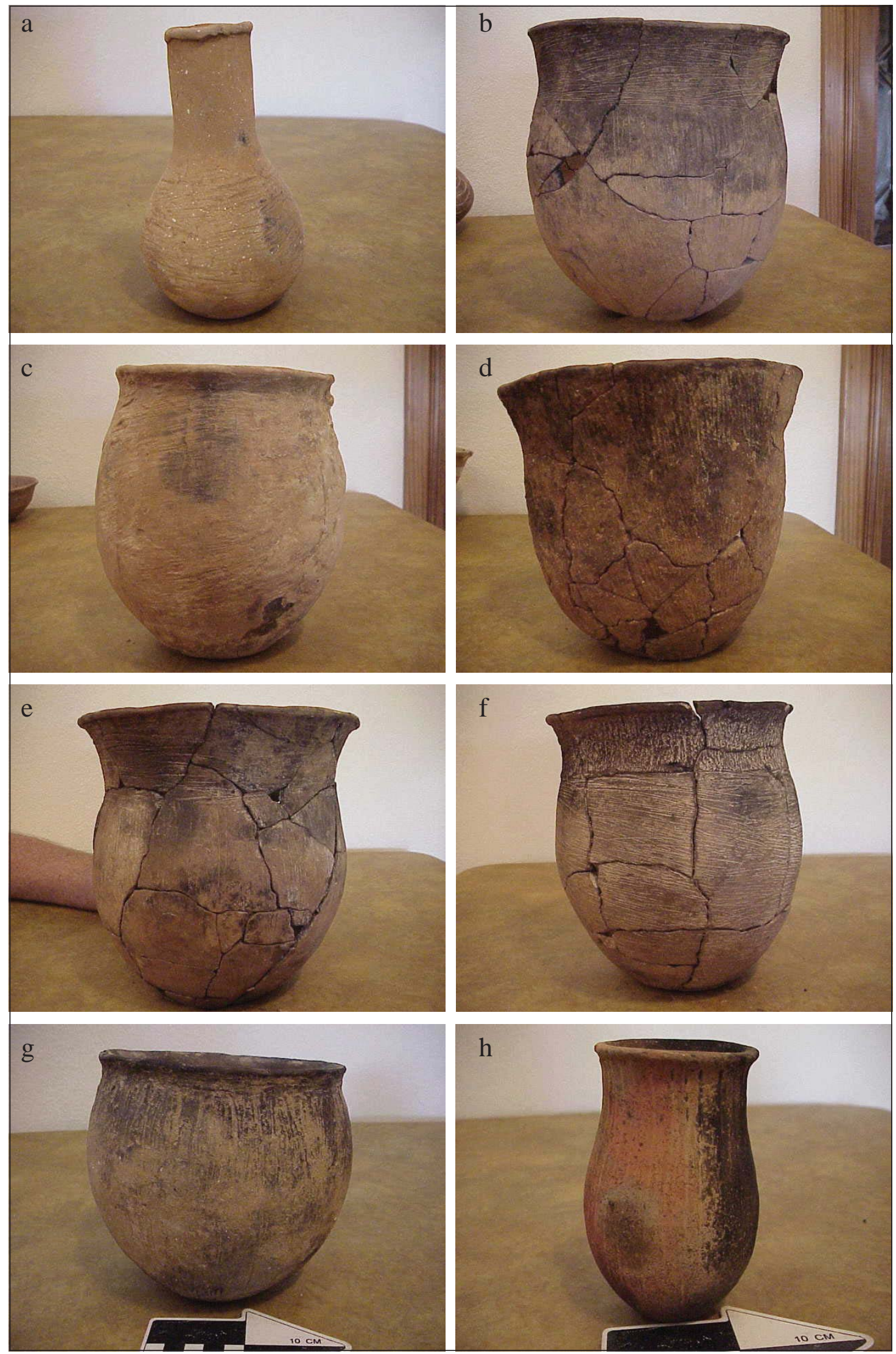

Figure 3. Brushed utility ware vessels in the Keasler collection from the Keasler site (41HS2355). 


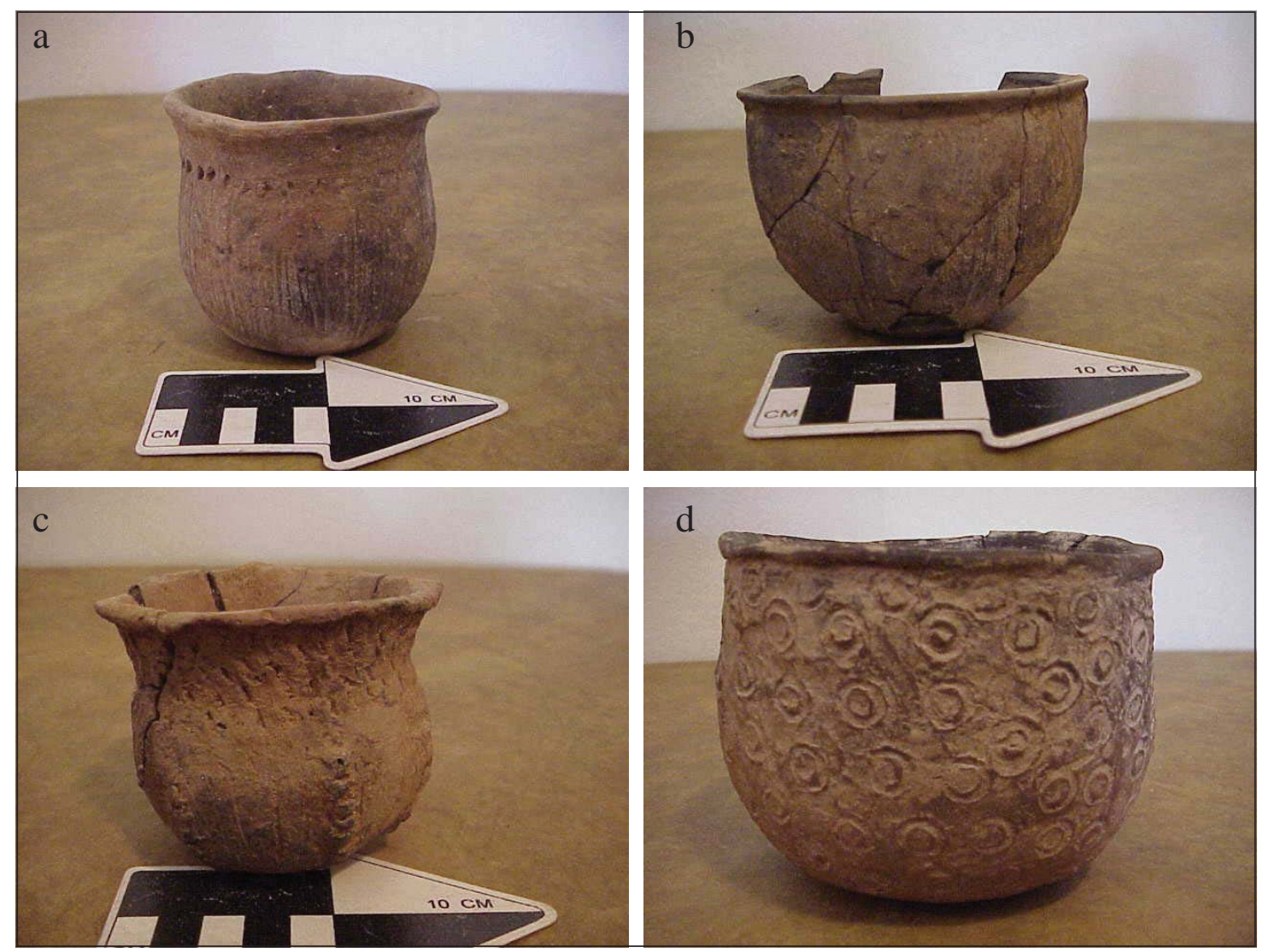

Figure 4. Other utility ware vessels in the Keasler collection from the Keasler site (41HS235).

There is one Harleton Appliqued jar in the Keasler collection (Figure 5). This everted rim jar has four rim peaks, four large strap handles with appliqued nodes, and scrolls of appliqued ridges on the vessel body. The rim and upper body of the vessel have triangular and diagonal opposed incised elements.

The remaining utility ware jars in the Keasler collection have incised $(n=1)$ or incised-punctated $(=3)$ decorative elements. The incised jar, probably Karnack Brushed-Incised, has a continuous series of vertical incised lines on the vessel body (Figure 6a). The incised-punctated jars have rows of tool punctations on the vessel rim and diagonal opposed (Figure 6b) or vertical (Figure 6c) incised lines on the vessel body.

\section{Fine Ware Vessels}

By far the largest proportion of ceramic vessels in the Keasler collection from the Keasler site are fine wares, that is, vessels decorated with engraved motifs and elements. There are 44 fine ware vessels in the collection (63.8 percent of the assemblage), including bottles ( $n=10,22.7$ percent), a deep bowl $(n=1,2.3$ percent), bowls ( $\mathrm{n}=2,4.5$ percent), and carinated bowls ( $\mathrm{n}=31,70.5$ percent).

The engraved bottles include a Bailey Engraved bottle with engraved-punctated decorative elements (Figure 7a), two other bottles with unusual combinations of engraved and punctated elements (Figure 7b-c), and a Hodges Engraved, var. Candler spool-necked bottle (Figure 7d) (see Schambach and Miller 1984:122). There is also a Taylor Engraved bottle (Figure 7e), a Ripley Engraved, var. Ripley bottle (Figure 7f), and four Wilder Engraved bottles (Figure 7g-i). 


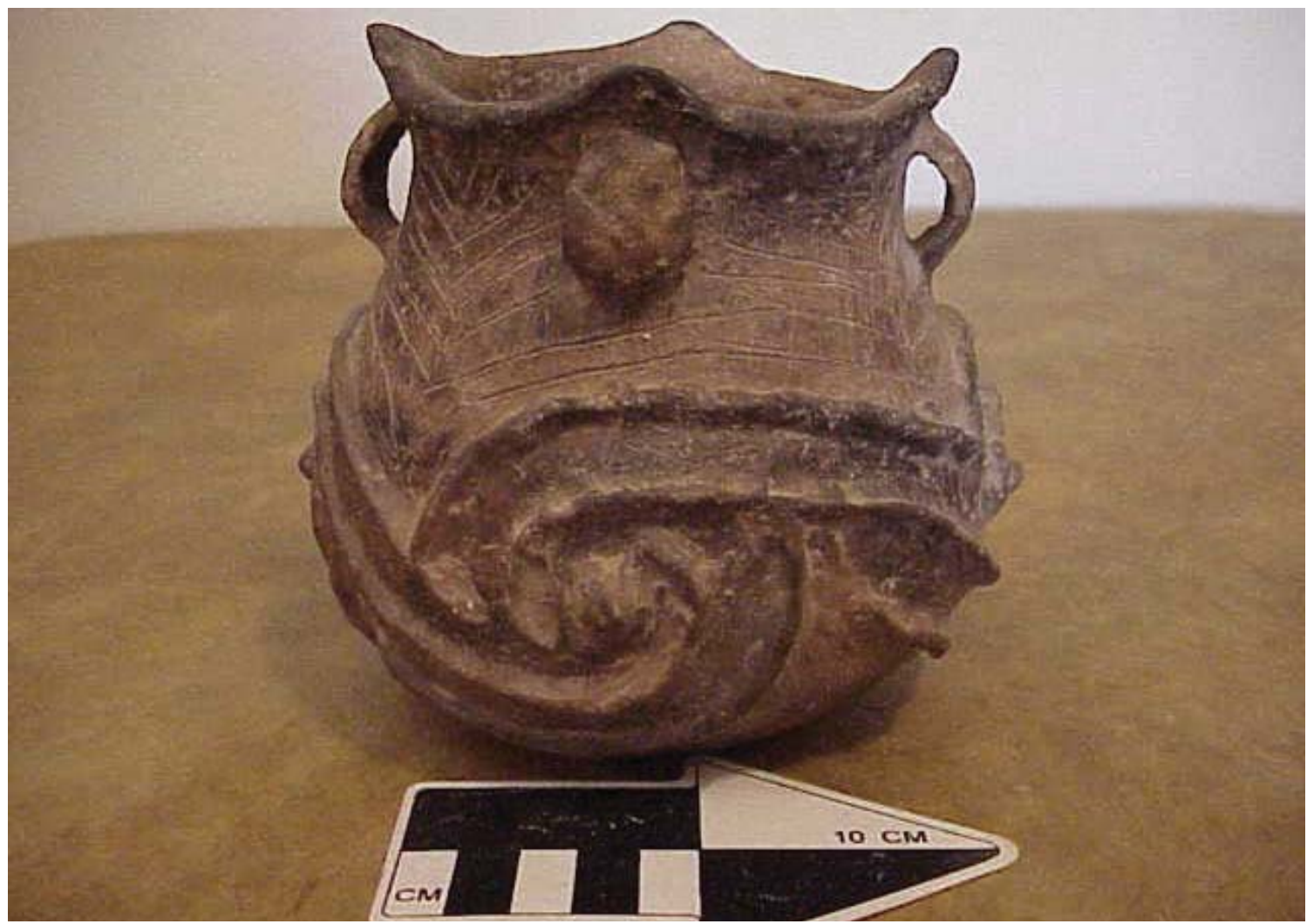

Figure 5. Harleton Appliqued jar in the Keasler collection from the Keasler site (41HS235).
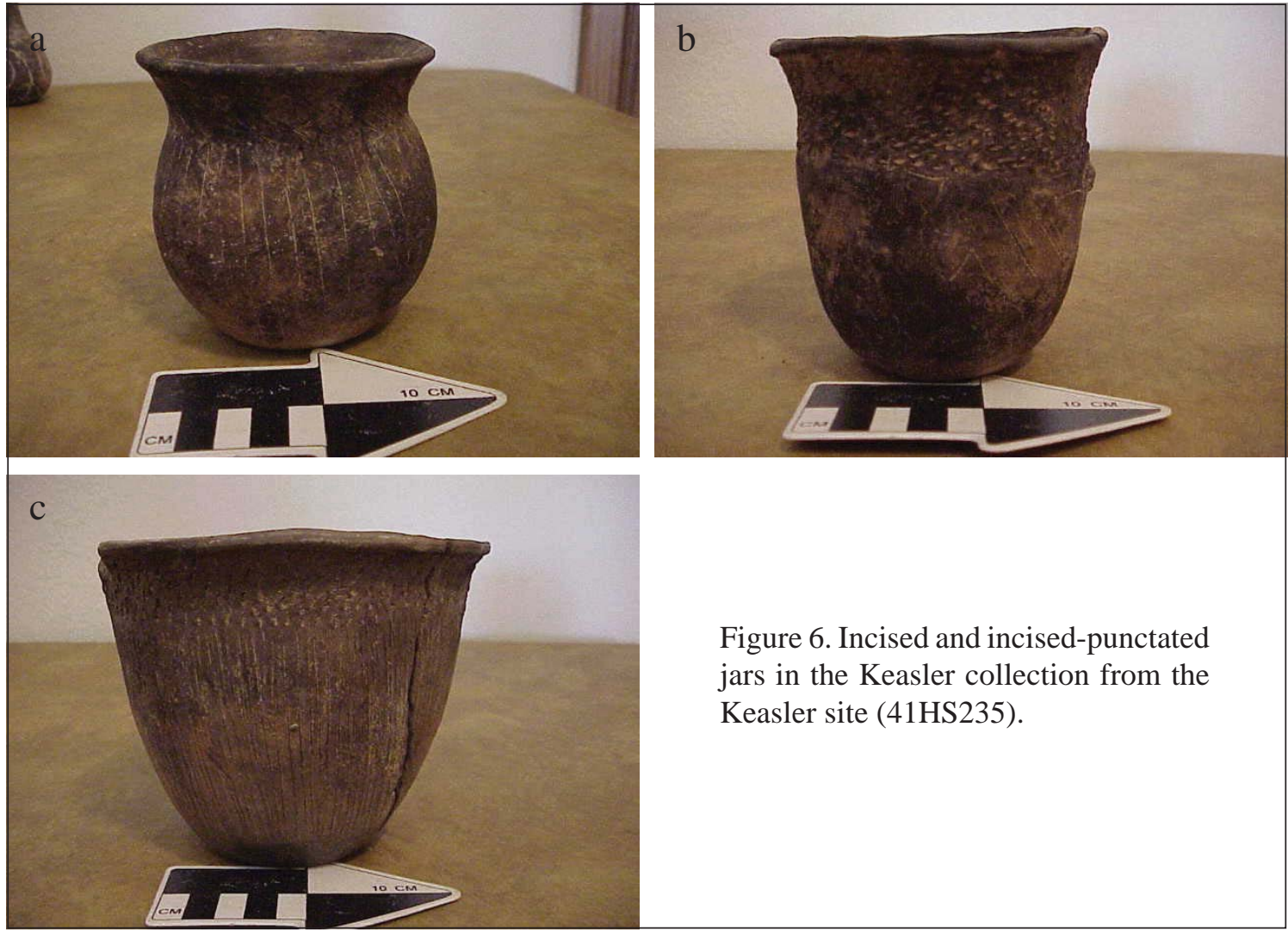

Figure 6. Incised and incised-punctated jars in the Keasler collection from the Keasler site (41HS235). 

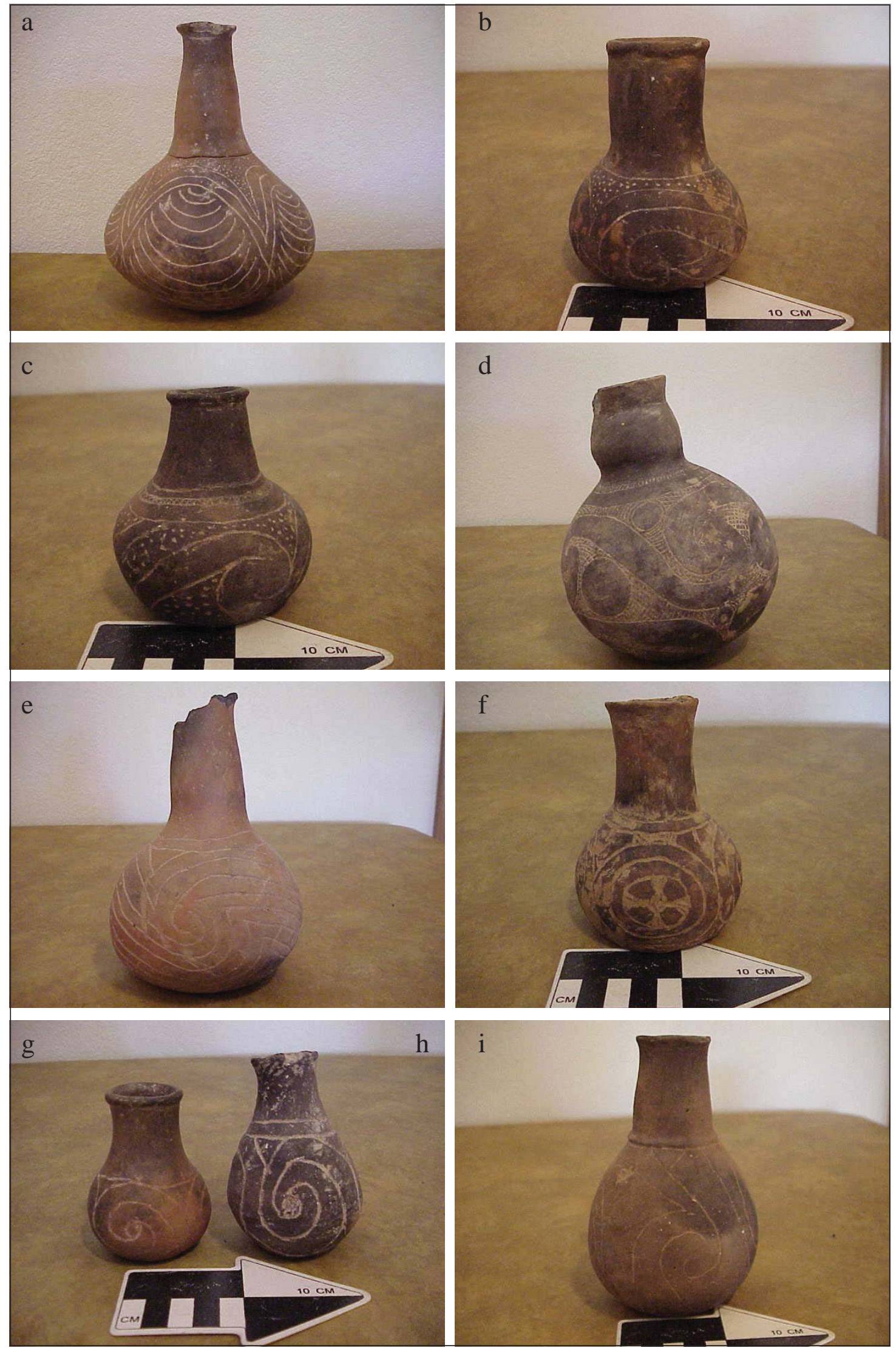

Figure 7. Engraved bottles in the Keasler collection from the Keasler site (41HS235). 
The one deep bowl is an Avery Engraved vessel (Figure 8), likely obtained from a McCurtain phase Caddo population living in the middle Red River basin. One of the bowls is a Hood Engraved effigy vessel with a clay bird head effigy at one end of the vessel and a flat tab tail at the other end (Figure 9a-b); the vessel has three horizontal engraved lines on the rim, and these lines dip underneath the effigy head. The other bowl has a series of upper and lower engraved and excised pendant triangles.

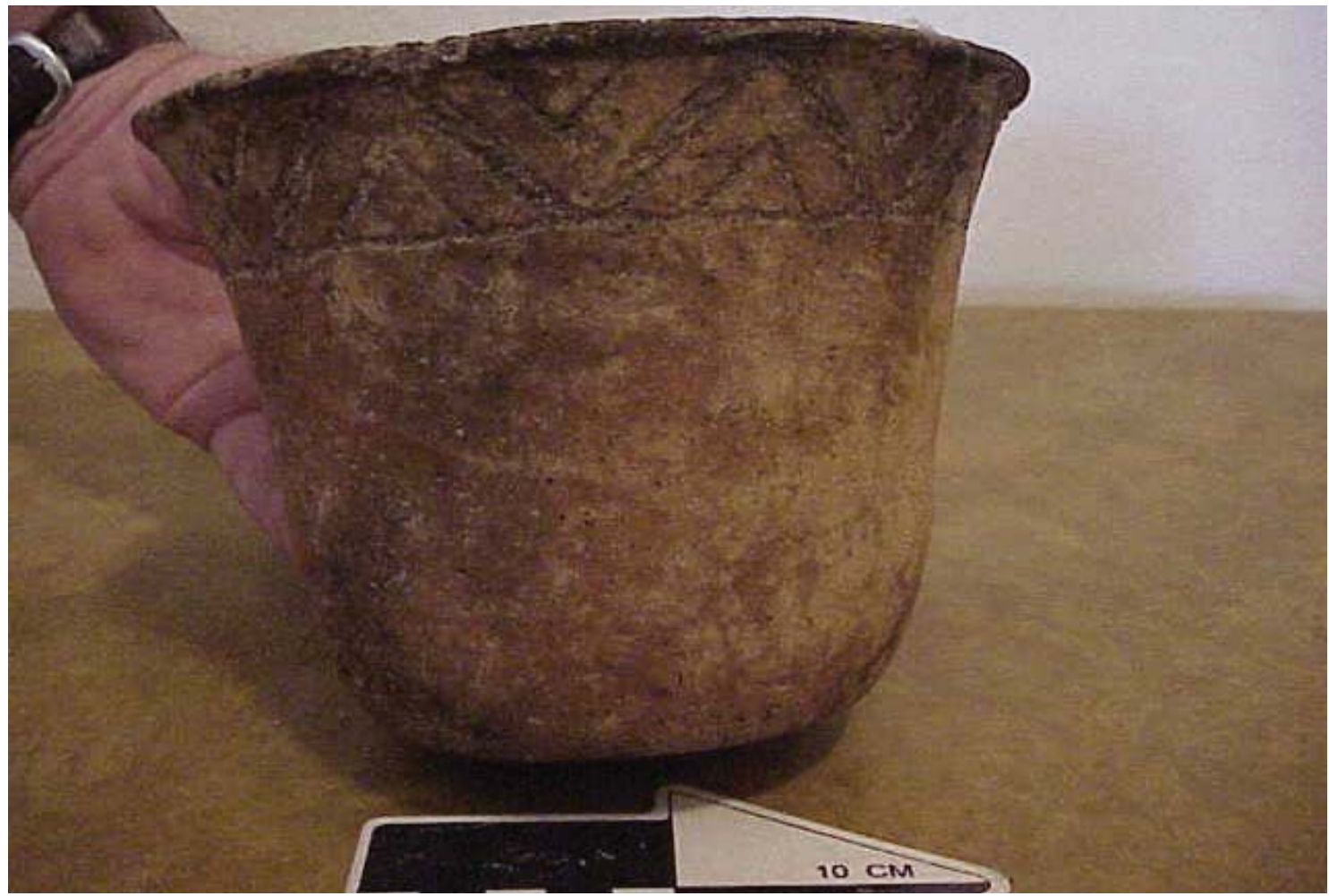

Figure 8. Avery Engraved deep bowl in the Keasler collection from the Keasler site (41HS235).

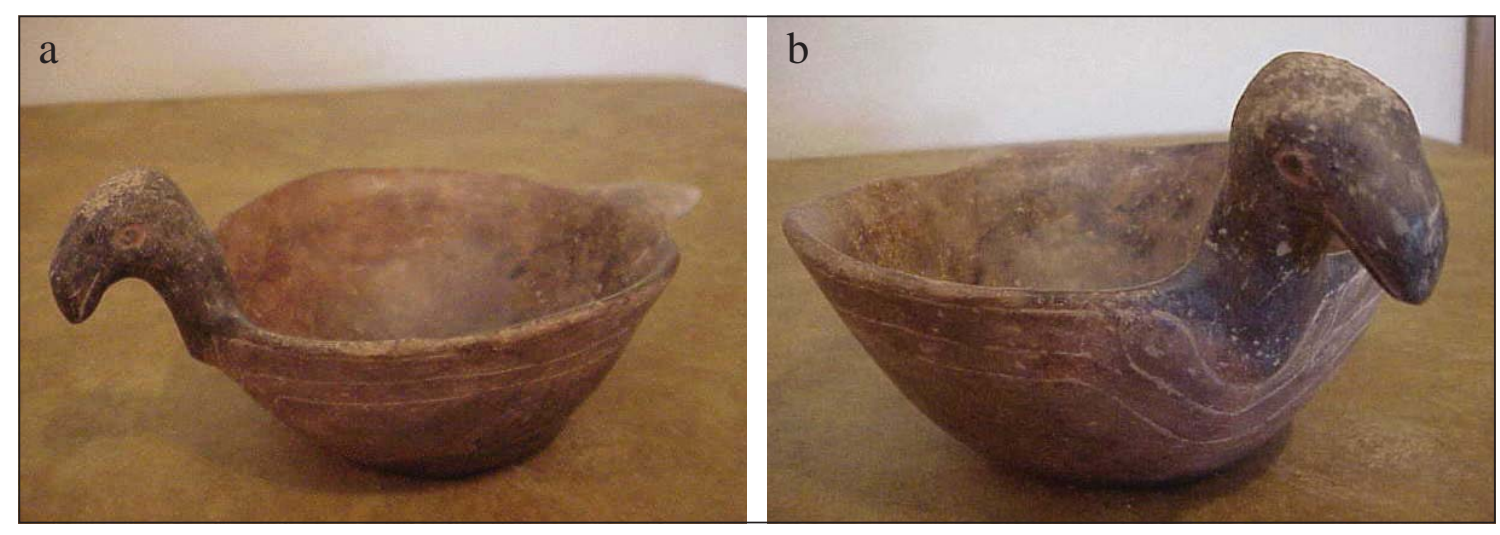

Figure 9. Effigy bowl in the Keasler collection from the Keasler site (41HS235).

Of the engraved carinated bowls in the Keasler collection from the Keasler site, 23 are Ripley Engraved vessels (74.2 percent), and there are also Taylor Engraved $(n=4)$ (Figure 10a-c), Barkman Engraved $(n=1)$ (Figure 10d), and Simms Engraved ( $\mathrm{n}=1$ ) (Figure 10e) carinated bowls in the collection. Two other engraved carinated bowls are unidentified to a defined type. The first (Figure 10f) is an inverted rim carinated bowl with sideways negative SZ elements on the rim divided by brackets, and the vessel body has curvilinear hooked elements with hatched lines. The other has a series of large engraved triangle elements on the rim around the vessel (Figure 10g). 

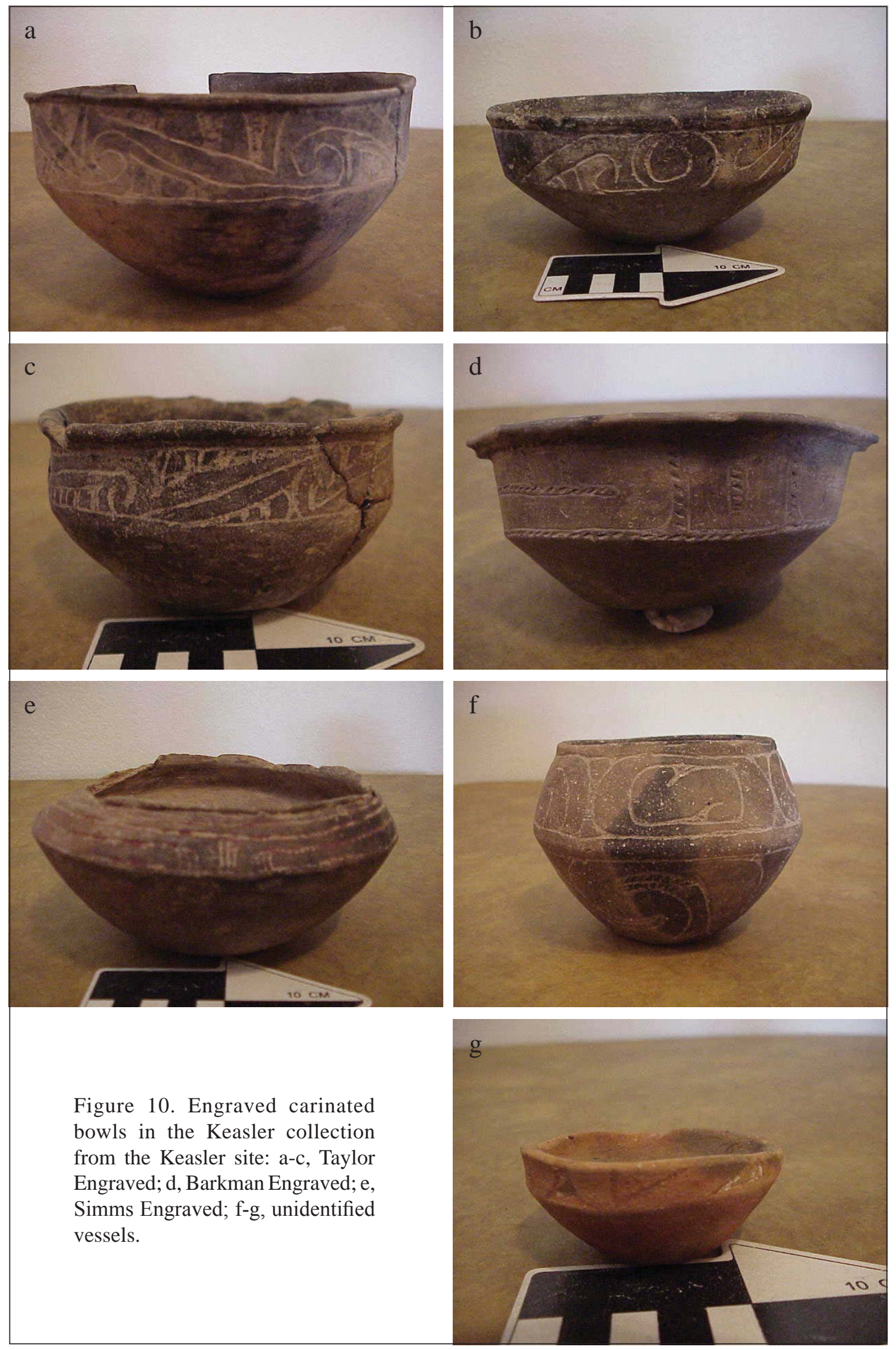

Figure 10. Engraved carinated bowls in the Keasler collection from the Keasler site: a-c, Taylor Engraved; d, Barkman Engraved; e, Simms Engraved; f-g, unidentified vessels. 
The Ripley Engraved carinated bowls in the collection can be assigned to a number of recently defined different varieties (see Fields et al. 2014; Perttula et al. 2012). The most common recognized varieties are var. Galt ( $\mathrm{n}=7$, one with lip tabs) (Figure 11a-e) and var. Williams $(\mathrm{n}=4)$ (Figure 12a-c), with much lower frequencies of var. Carpenter $(\mathrm{n}=2)$ (Figure 12d-e), var. Gandy $(\mathrm{n}=2$, including one with an oval eye element) (Figure 13a), var. McKinney $(\mathrm{n}=2)$ (Figure 13b-c), var. McKinney-Enis Smith $(\mathrm{n}=1)$ (Figure 13d), var. Caldwell $(\mathrm{n}=1)$ (Figure 14a), var. Pilgrim's $(\mathrm{n}=1)$, and var. Tiddle $(\mathrm{n}=1)$ (Figure 14b). Another two Ripley Engraved vessels cannot be identified to a defined variety (Figure 15a-b), and are considered var. unspecified.
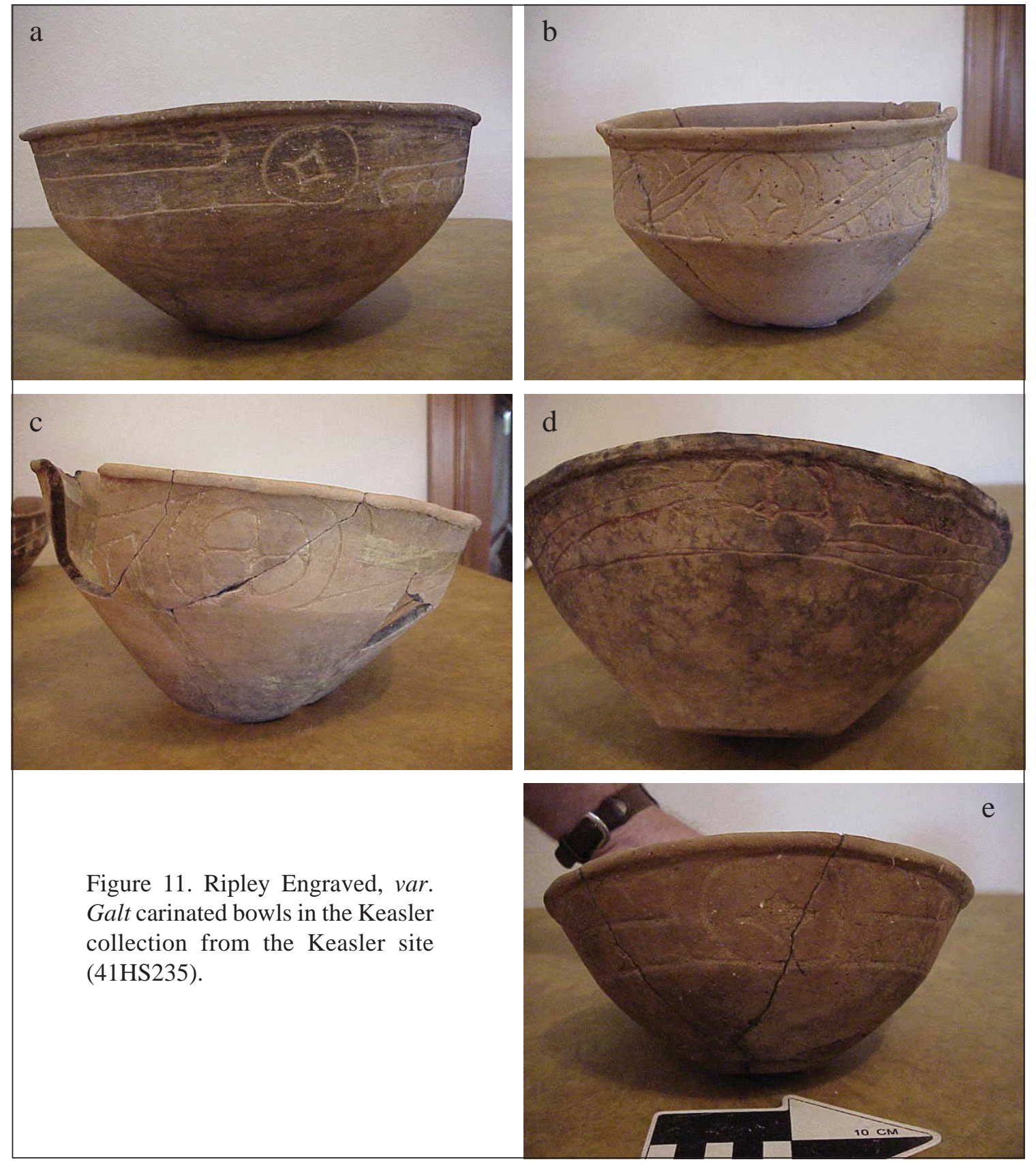

The wide variety of varieties of Ripley Engraved carinated bowls in the Keasler site cemetery indicate that potters in Little Cypress Creek basins manufactured very distinctive fine wares over perhaps several generations that were eventually selected to be used as funerary offerings These particular fine wares have scroll and circle motifs (var. Galt), alternate nested triangle motifs (var. Williams), scrolls, and pendant triangle elements. 

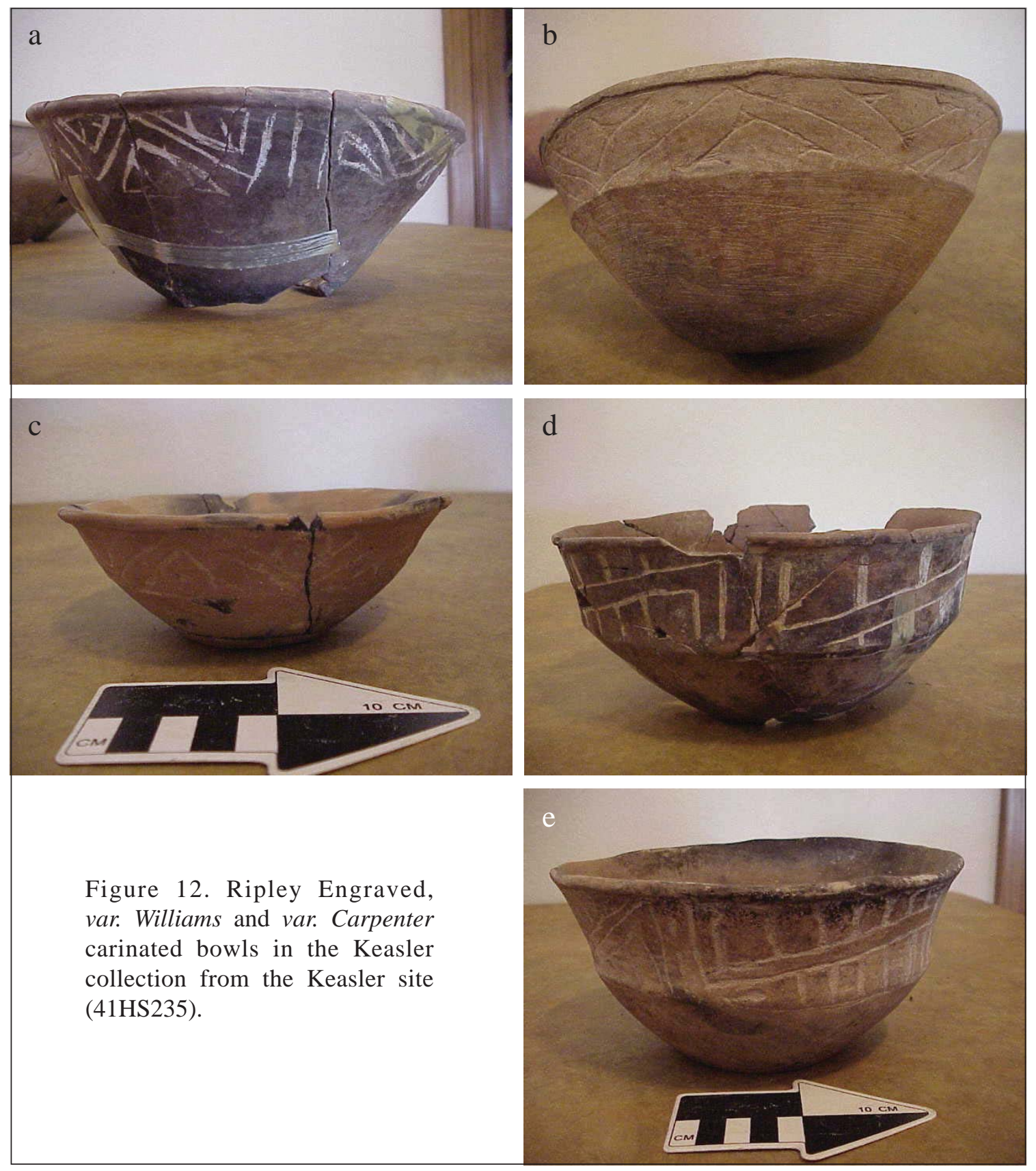

\section{Ceramic Pipes}

One of the ceramic pipes in the Keasler collection is the stem to a long-stemmed Red River pipe (Figure 16, top left). Such pipes, with long stems and small undecorated bowls, are considered to be a pipe form made by Caddo peoples across the Caddo area until the early $15^{\text {th }}$ century A.D. (Hoffman 1967). That it is a stem sherd rather than a complete pipe suggests that this artifact may not have been a funerary offering per se, but an incidental inclusion in a Late Caddo period burial feature at the Keasler site.

The other two ceramic pipes are both decorated elbow pipes (see Figure 16). One is decorated on the top side with a rectangular engraved motif and a horizontal engraved line below the lip of the pipe stem, and the bottom flat side of the pipe has an oval "eye" motif with inner circle and triangle elements (see Figure 16, top). The oval "eye" motif, while not common, is present on several ceramic vessels in other East Texas Titus 

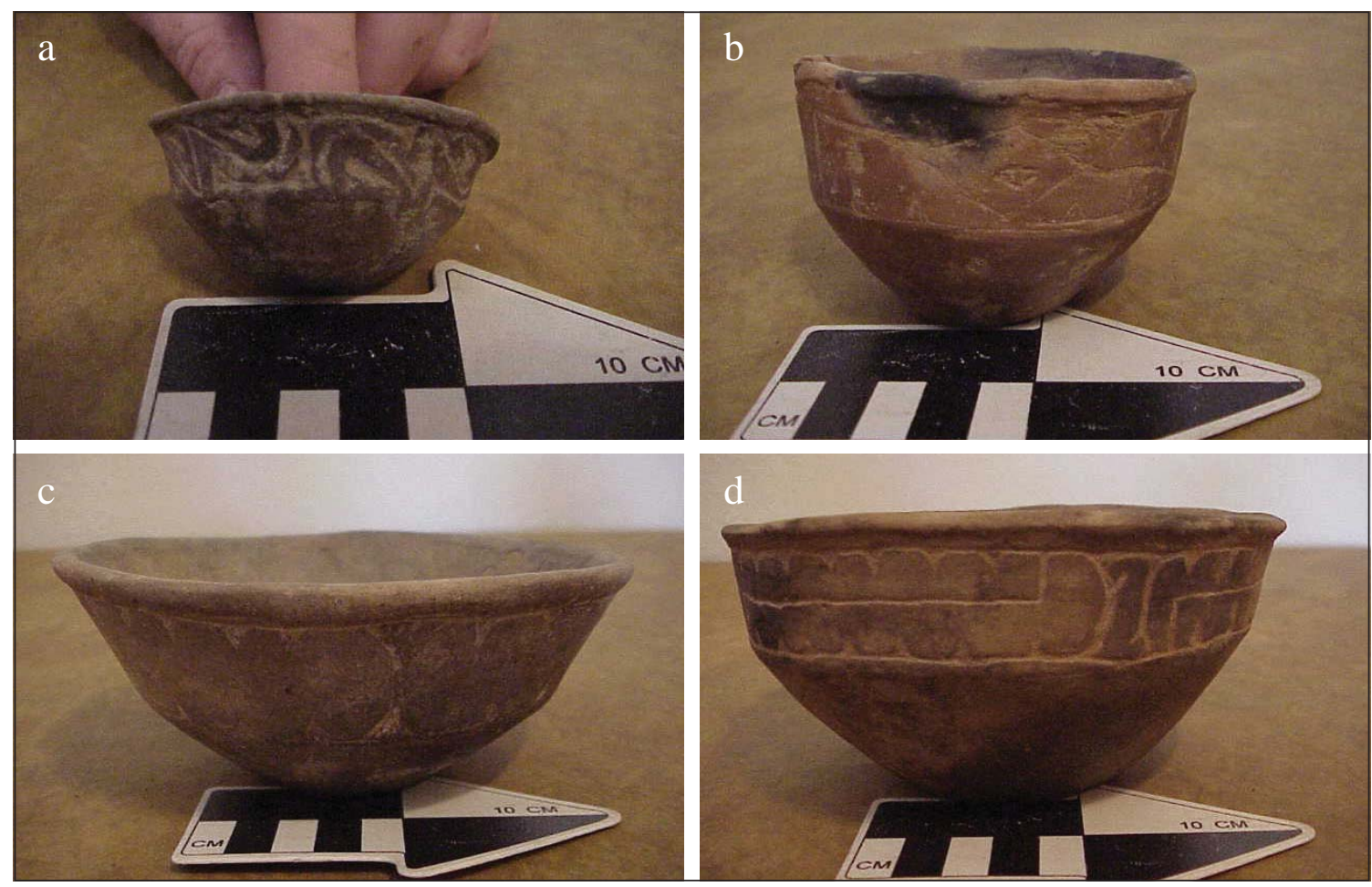

Figure 13. Ripley Engraved, var. Gandy, var. McKinney, and var. McKinney-Enis Smith carinated bowls in the Keasler collection from the Keasler site (41HS235).

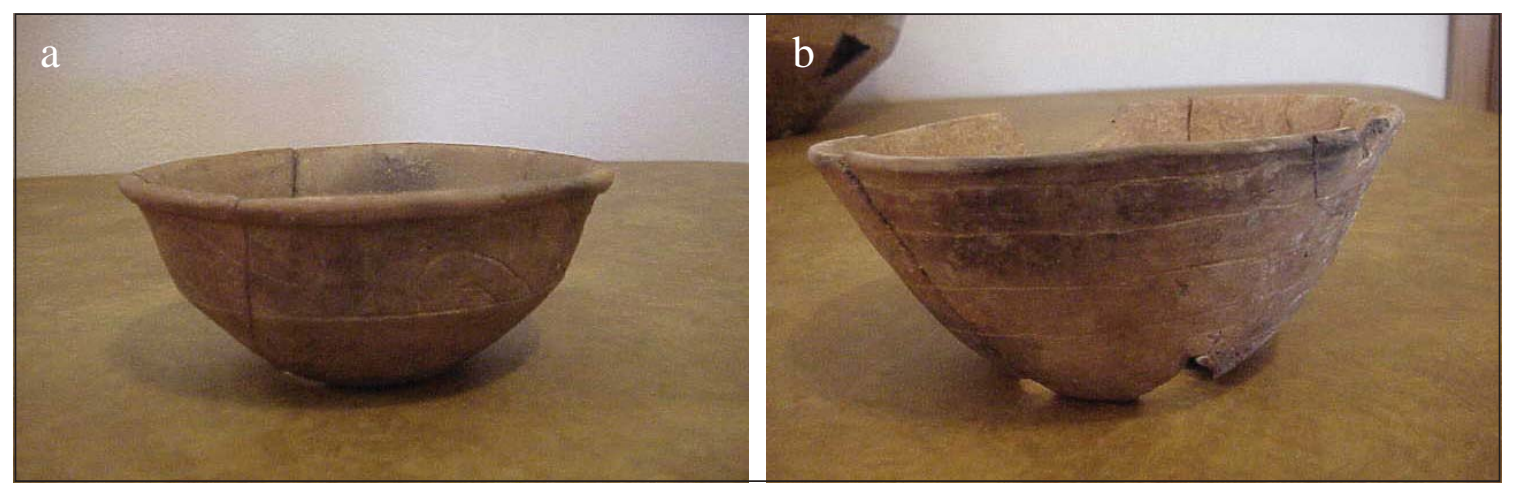

Figure 14. Ripley Engraved, var. Caldwell and var. Tiddle carinated bowls in the Keasler collection from the Keasler site (41HS235).

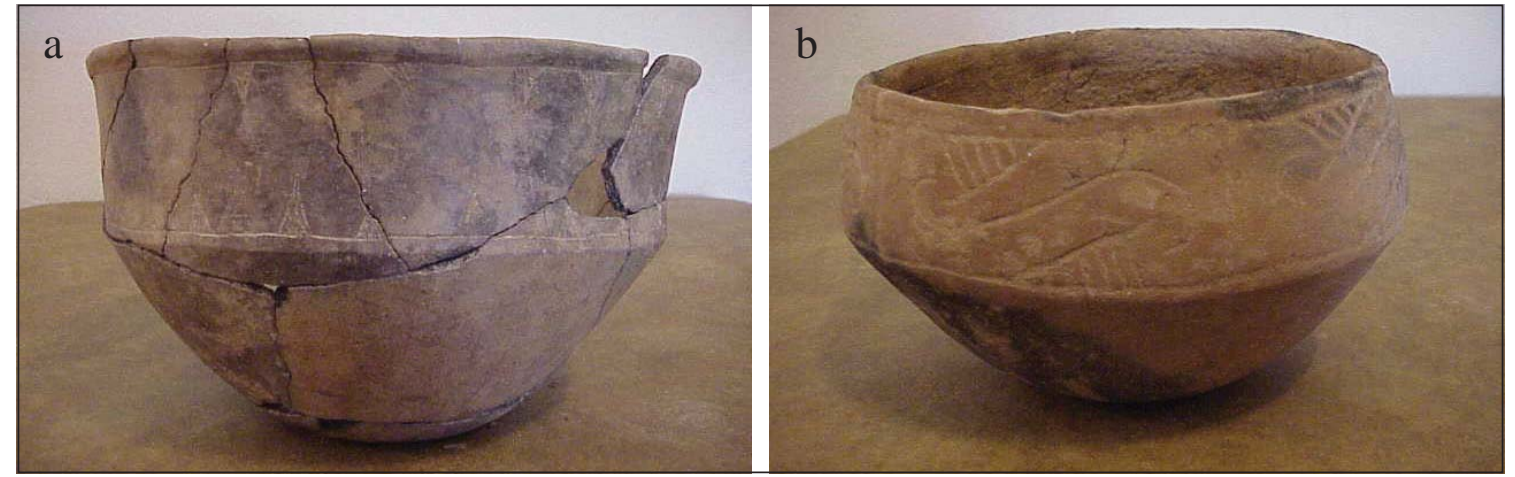

Figure 15. Ripley Engraved, var. unspecified carinated bowls in the Keasler collection from the Keasler site. 


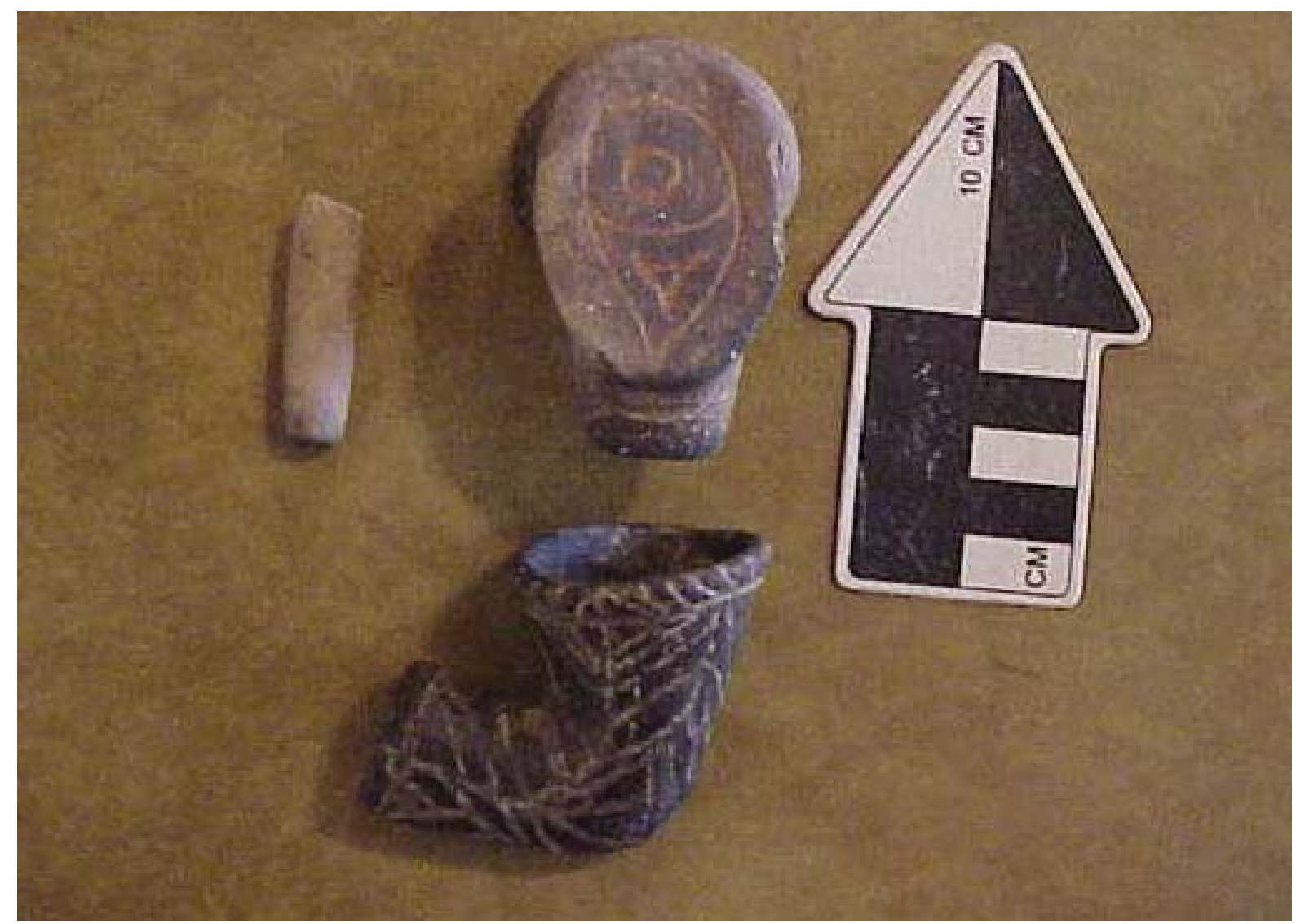

Figure 16. Ceramic pipes in the Keasler collection from the Keasler site.

phase contexts, as well as on one vessel in the Keasler collection (see Figure 13a), as well as on a carinated bowl from the $18^{\text {th }}$ century Kinsloe phase Millsey Williamson site (41RK3) in the mid-Sabine River basin (see Perttula and Nelson 2014). The second elbow pipe in the collection has a rounded elbow, with short stem and bowl (see Figure 16, bottom). The pipe has been decorated on the bowl lip with a series of short vertical engraved lines, and there are also a series of longer vertical engraved lines on the remainder of the bowl. The stem has been decorated with vertical and diagonal opposed engraved lines, along with a single horizontal engraved line encircling the lower part of the stem.

\section{Arrow Points}

The 17 arrow points among the funerary offerings are dominated by triangular Talco points ( $n=13)$, almost all of them made on local quartzite raw materials (Figure 17, top two rows and the three on the left of the third row). Two other arrow points are smaller Maud triangular points, also on local raw materials (Figure 17, two points on the right on the third row). There is also a single Bassett point made from a local yellowish-red chert and a quartzite Perdiz arrow point among the funerary collections from the Keasler cemetery (bottom row, left to right). The predominance of triangular arrow points in the funerary collection indicates they came from Titus phase burials postdating ca. A.D. 1550.

\section{Celts}

Among the funerary offerings in the Keasler collection are five ground stone celts made from Ouachita Mountains igneous rocks, including graywacke and siliceous shale (Figure 18). The celts have rounded butt ends and bifacially polished bits, and they are were in various phases of use, resharpening, and recycling when they were placed in the graves of Caddo peoples in the Keasler cemetery. 


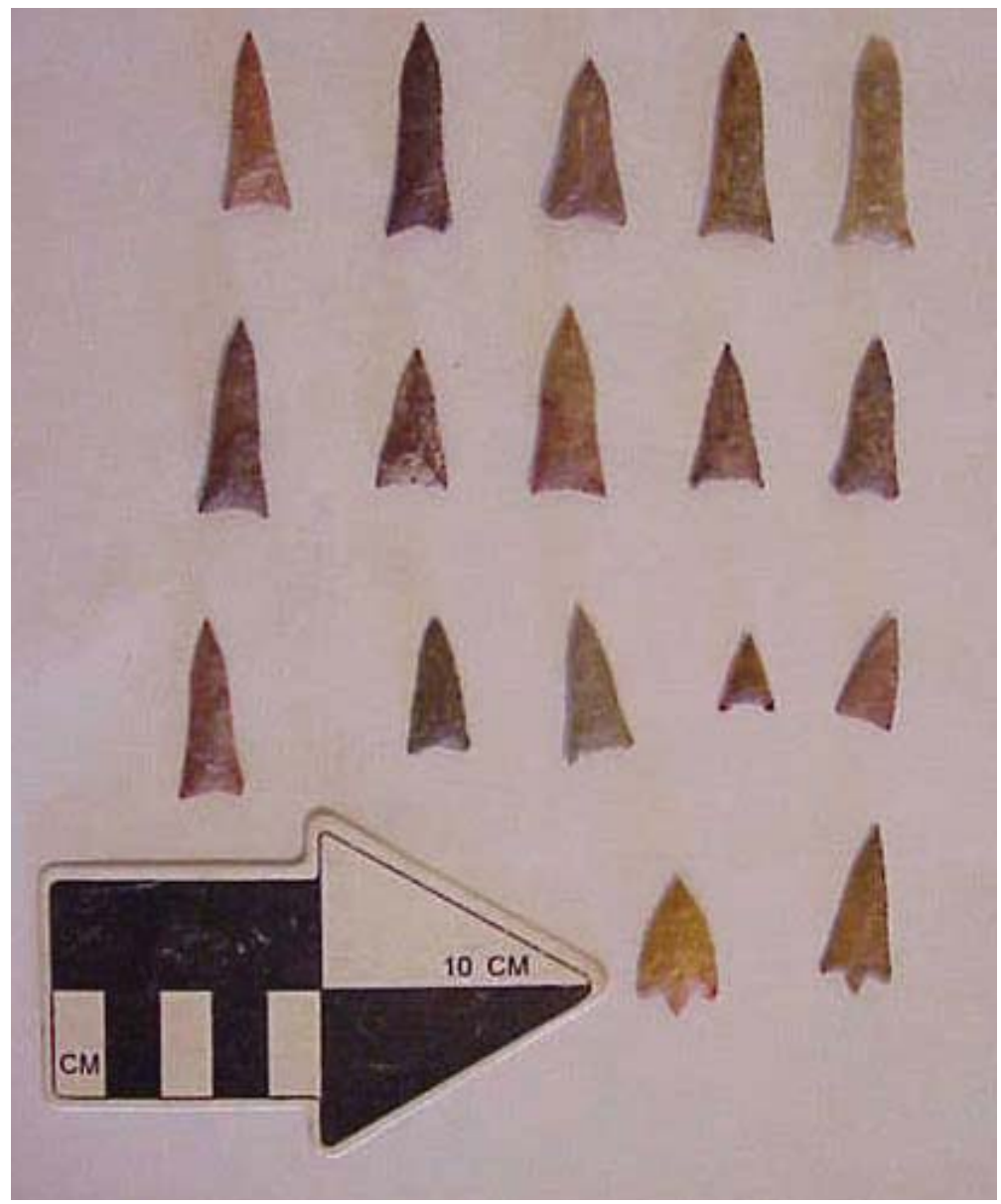

Figure 17. Arrow points in the Keasler collection from the Keasler site (41HS235).

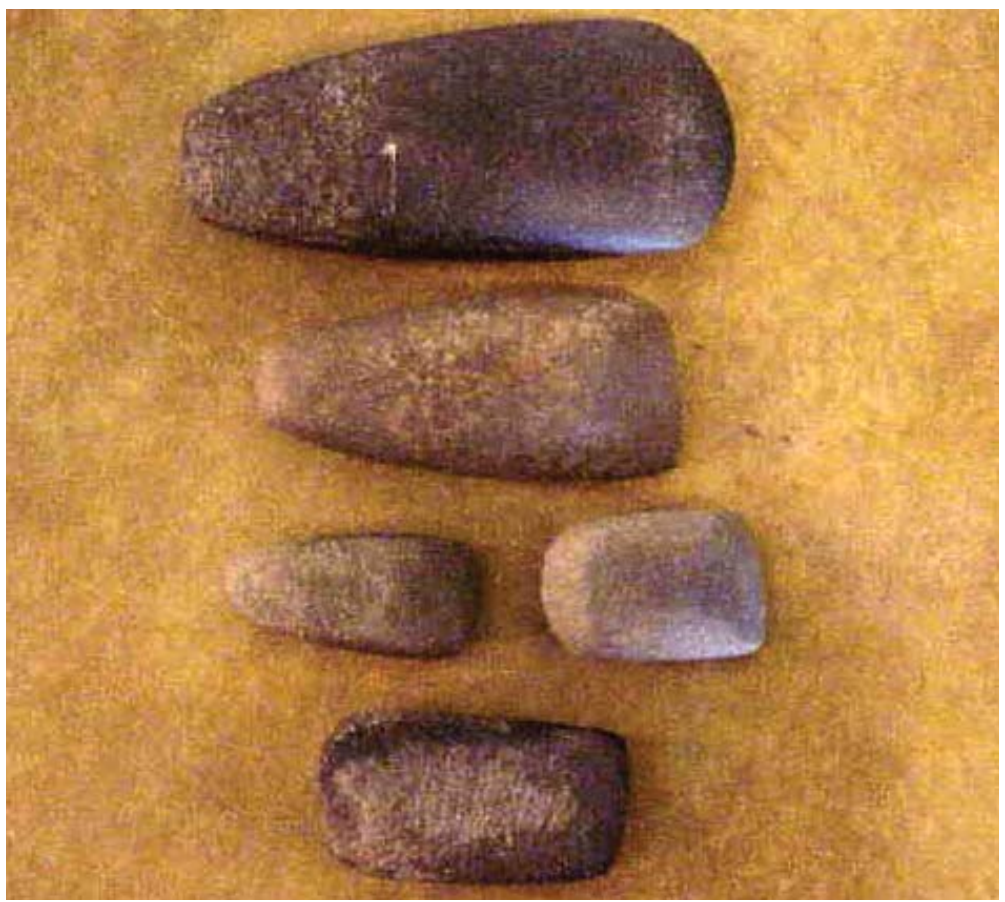

Figure 18. Ground stone celts in the Keasler collection from the Keasler site (41HS235). 


\section{SUMMARY AND CONCLUSIONS}

The Sid Keasler collection of funerary offerings from the Titus phase Keasler site cemetery (41HS235) was photo-documented in July 1999 by Mark Walters and Bo Nelson. These offerings were given to Mr. Keasler by Red McFarland, one of the collectors that excavated more than 30 ancestral Caddo burials from the cemetery in the 1970s. These funerary offerings from a Titus phase cemetery at its southeastern boundary provides significant information on the character of the mortuary goods placed in burials of Caddo peoples in this part of the East Texas Pineywoods (see also Perttula 2015). The funerary offerings included arrow points - primarily of the Talco type-as well as ground stone celts, ceramic elbow pipes with engraved decorations, and a wide variety of ceramic vessels representing plain ware, utility ware, and fine ware.

Plain wares include bottles, bowls, carinated bowls, and a jar, while utility wares include Bullard Brushed, Belcher Ridged, Cass Appliqued, Harleton Appliqued, and Karnack Brushed-Incised jars. The presence of at least two Belcher Ridged and Cass Appliqued vessels suggests use of the cemetery after (and perhaps well after in the case of Cass Appliqued) ca. A.D. 1500. Fine ware vessels in burial features include at least 10 varieties of Ripley Engraved (var. Carpenter, var. Caldwell, var. Galt, var. Gandy, var. McKinney, var. McKinney-Enis Smith, var. Pilgrim's, var. Richey, var. Tiddle, var. Williams, and var. unspecified) carinated bowls and compound bowls (see Perttula et al. 2012; Fields et al. 2014:Table 8-6); several of the carinated bowls have brushed vessel bodies (Perttula 2015:Figures 6-7). There are also Bailey Engraved, Hood Engraved (an effigy bowl), Taylor Engraved, Simms Engraved, Hodges Engraved, Avery Engraved, Barkman Engraved, Wilder Engraved, var. Wilder bottles and/or engraved carinated bowls, and a Ripley Engraved, var. Ripley bottle.

The range of varieties of Ripley Engraved vessels as well as other utility and fine wares among the funerary offerings suggests that this Titus phase cemetery may have been used for several generations in the $16^{\text {th }}$ and $17^{\text {th }}$ century. Ripley Engraved, var. McKinney may well be a post-A.D 1600 variety of ceramic vessel, as is Hodges Engraved, var. Candler, and the Talco arrow points. Nevertheless, the chronological ordering of the many varieties of Ripley Engraved and other Titus phase ceramic vessel funerary offerings have yet to be fully established through either radiocarbon dating or the seriation of burial features (cf. Fields et al. 2014). Recent findings summarized by Fields et al. (2014:476) suggest there is also much more work to be done to establish the existence and relationship of communities in the Titus phase, or the extent of cultural transmission between different communities over as much as 250+ years in the Big and Little Cypress Creek and Sabine River basins in East Texas.

\section{ACKNOWLEDGMENTS}

We thank Mr. Sid Keasler for the opportunity to photo-document the collection of funerary offerings from the Keasler site cemetery.

\section{REFERENCES CITED}

Burden, D., R. C. Fields, E. F. Gadus, and V. L. Hatfield

2014 The Thomas Caldwell and A. P. Williams Cemeteries and Titus Phase Mortuary Behavior. In Testing and Data Recovery Excavations at 11 Native American Archeological Sites along the U.S. Highway 271 Mount Pleasant relief Route, Titus County, Texas, by R. C. Fields, V. L. Hatfield, D. Burden, E. F. Gadus, M. C. Wilder, and K. W. Kibler, pp. 335-433. 2 Vols. Reports of Investigations No. 168. Prewitt and Associates, Inc., Austin.

Fields, R. C., V. L. Hatfield, D. Burden, E. F. Gadus, M. C. Wilder, and K. W. Kibler

2014 Testing and Data Recovery Excavations at 11 Native American Archeological Sites along the U.S. Highway 271 Mount Pleasant relief Route, Titus County, Texas. 2 Vols. Reports of Investigations No. 168. Prewitt and Associates, Inc., Austin. 
Hoffman, M. P.

1967 Ceramic Pipe Style Chronology Along the Red River Drainage In Southwestern Arkansas. The Arkansas Archeologist 8(1):4-14.

Perttula, T. K.

2012 The Character of Fifteenth- to Seventeenth-Century Caddo Communities in the Big Cypress Creek Basin of Northeast Texas. In The Archaeology of the Caddo, edited by T. K. Perttula and C. P. Walker, pp. 363-410. University of Nebraska Press, Lincoln.

2015 The Keasler Site (41HS235), a Titus Phase Cemetery in the Little Cypress Creek Basin, Harrison County, Texas. Journal of Northeast Texas Archaeology 54:9-19.

Perttula, T. K. and B. Nelson

2014 The Millsey Williamson (41RK3), Bead Burial, and L. N. Morwell Farm Sites on Martin Creek: Historic Caddo Settlements along Trammels Trace, Rusk County, Texas. Journal of Northeast Texas Archaeology 44:23-46.

Perttula, T. K., B. Nelson, and M. Walters

2012 Caddo Archaeology at the Henry Spencer Site (41UR315) in the Little Cypress Creek Basin of East Texas. Special Publication No. 20. Friends of Northeast Texas Archaeology, Pittsburg and Austin.

Schambach, F. F. and J. E. Miller

1984 A Description and Analysis of the Ceramics. In Cedar Grove: An Interdisciplinary Investigation of a Late Caddo Farmstead in the Red River Valley, edited by N. L. Trubowitz, pp. 109-170. Research Series No. 23. Arkansas Archeological Survey, Fayetteville. 